\title{
ASSESSING STREET-LEVEL DISTRIBUTION OF TREE OF HEAVEN (AILANTHUS ALTISSIMA) IN ISTANBUL (TURKEY)
}

\author{
ULUS, A. ${ }^{1}-$ YILMAZ, H..$^{2 *}$ AKKEMIK, Ü. ${ }^{3}-$ YILMAZ, O. Y. ${ }^{4}$ \\ ${ }^{1}$ Istanbul University-Cerrahpasa, Landscape Architecture, Department of Plant Material and \\ Propagation Techniques, Istanbul, Turkey \\ (phone: +90-212-338-2400; fax: +90-212-226-1113) \\ ${ }^{2}$ Istanbul University-Cerrahpasa, Vocational School of Forestry, Landscape and Ornamental \\ Plants Program, Bahçeköy - İstanbul, Turkey \\ (phone: +90-212-338-2400; fax: +90-212-338-2428) \\ ${ }^{3}$ Istanbul University-Cerrahpasa, Faculty of Forestry, Forest Engineering, Department of \\ Forest Botany Bahçeköy - İstanbul, Turkey \\ (phone: +90-212-338-2400; fax: +90-212-226-1113) \\ ${ }^{4}$ Istanbul University-Cerrahpasa, Faculty of Forestry, Forest Engineering, Department of \\ Surveying and Cadastre, Istanbul, Turkey \\ (phone: +90-212-338-2400; fax: +90-212-226-1113) \\ ${ }^{*}$ Corresponding author \\ e-mail: yilmazhc@istanbul.edu.tr; phone: +90-212-338-2400; fax: +90-212-338-2428
}

(Received 29 $9^{\text {th }}$ Jan 2021; accepted $9^{\text {th }}$ Apr 2021)

\begin{abstract}
Tree of heaven (Ailanthus altissima (Mill.) Swingle) from the Simaroubaceae family is recognized as an invasive species within urban, rural, and natural ecosystems in many parts of the world. There is no regional or national strategy for the management and control of A. altissima in Turkey, where it is also accepted as an invasive plant species and occurs in many cities. Google Street View images were used in the study for virtual inventory of street trees. This study has been conducted to reveal the presence of the tree of heaven in the streets of Istanbul, 8 very large, 45 large, 110 medium, 155 small, 80 very small single plants were detected in 7720 sample plots with a length of 50 meters. The average ratio of tree of heaven to the total street tree species composition was $2 \%$, while this rate is $0.5 \%$ in some districts, it rises up to $6 \%$ in some others. This indicated that A. altissima was widespread even though it was not planted as a street tree on the roadsides of Istanbul.
\end{abstract}

Keywords: street trees, invasive alien species, virtual survey, tree identification, street view images

\section{Introduction}

Ailanthus altissima (Mill.) Swingle, commonly called tree of heaven, is a dioecious, deciduous, medium sized tree. Tree of heaven, which is native to China, was introduced to France as early as the 1740's and soon after became widely planted in European cities because of its fast growth and attractive foliage (Hu, 1979). In a short period, it naturalized elsewhere and has become invasive everywhere except for Antarctica (Kowarik and Säumel, 2007), Nordic countries and Russia (EPPO, 2018). Tree of heaven is also cultivated as an ornamental plant in many towns and along railways and is naturalized in Turkey (Cullen, 1967). It is one of the invasive plants of Turkey which grow on historical areas, forest edges, agricultural areas, railways and its plantation is continued without taking into consideration its invasive character. Therefore, it is obvious that it will be a much bigger problem in the future considering climate change scenarios in Turkey (Uludağ, 2015). 
Tree of heaven is among the top 20 alien invasive plants to control (Sheppard et al., 2006) as well as one of the leading alien woody species causing serious damage to infrastructure and public service utilities in Europe (Pysek et al., 2009) and it was recently inserted to the list of invasive alien species of Union concern (European commission 2019). A. altissima can regenerate from root fragments (Kowarik and Säumel, 2007) and root shoots can grow up to $183 \mathrm{~cm}$ per year (Asaro et al., 2009). Seed yield of this species, which start producing seeds as early as 4-5 years old, can exceed one hundred years (Wickert et al., 2017). Winged fruits can be transported long distances by wind and rivers and its seeds can remain viable more than 5 years in $10 \mathrm{~cm}$ depth soil (Rebbeck and Jolliff, 2018). The fact that tree of heaven is at the head of invasive woody plants is due to the species' strong root system, strong stump shoots, tolerance of poor soil and poor air quality, drought resistance, high germination rate, as well as its ability to give abundant seeds and spread the seed over long distances (Casella and Vurro, 2013).

Although it appears to be useful in regulating ecosystem services in such areas, as it grows well in urban and industrial environments with harsh living conditions where many tree species have difficulties to thrive (Kowarik and Säumel, 2007), the negative impacts of this tree are generally considered to be more than its benefits (Andreu et al., 2009). Because A. altissima arrives to many areas in cities such as walls, pavement cracks, roadsides, lands that are not regularly maintained, city parks (Kowarik and Säumel, 2007), historical and archeological buildings (Celesti-Grapow and Blasi, 2004) and quickly establishes as colonies. And once established, removing it from the area requires a very laborious, costly and time-consuming effort (Brundu, 2017).

Cities are primary habitats of the species (Slodanja et al., 2015) and roads also serve as prime habitats and corridors for invasive plant species (Kowarik and Lippe, 2011; Meunier and Lavie, 2012). There is a significant risk that invasive plants will spread from roadsides to adjacent natural habitats and adversely affect native plant communities (Follak et al., 2018).

In order to manage and control this invasive species, the degree of spreading and the damage should be determined first. In other words, it is critical to know their location, spread, and change over time, measure and evaluate their short and long-term effects, and plan their control.

In Istanbul, which is a historical metropolis, no studies have been performed to detect the presence of A. altissima, which is frequently seen on roadsides, city walls, abandoned lands, forest edges. The aim of this study is to conduct a road survey to detect the presence of this species on the roadside of Istanbul and to draw attention to the invasive feature of the species by making a general situation assessment, and to evaluate its presence on the streets of the European side of the megacity.

\section{Material and methods}

\section{Study area}

The study was conducted in 21 districts in the European side of İstanbul, Turkey, one of the most populated urban areas in the world (Figure 1). This city covers a current area of $5,343 \mathrm{~km}^{2}$, houses a human population that surpasses 15 million inhabitants (TUIK, 2020). There are 25 districts in the European side of the city and four of them, Arnavutköy, Çatalca, Büyükçekmece, and Silivri were excluded since they are far from the core areas of Istanbul and they are home to wide forests and agricultural areas around the roads. 


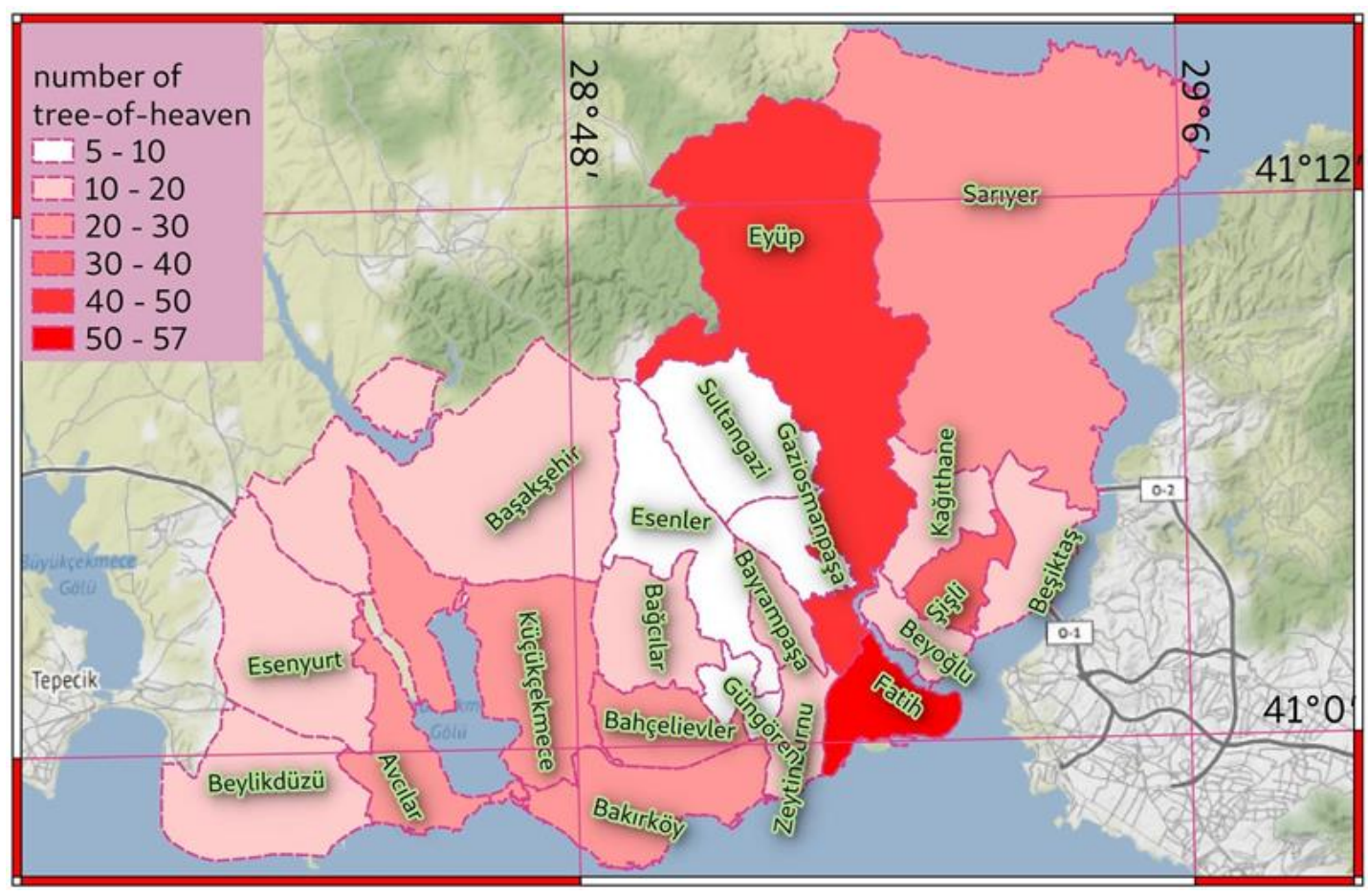

Figure 1. The 21 studied districts in the European side of Istanbul. Number of Ailanthus altissima trees corresponding to each district have graduated according to a color grid. The total number of "sample plots" with Ailanthus present are shown in the pie chart

\section{Data}

A vector map layer of district boundaries, Open Street road layer (OpenStreetMap contributors, 2019) and Google Street View images (Google, 2019) were used in the study for virtual inventory of street trees. Google Street View (GSV) images were used in several studies (Li et al., 2015a,b; Berland and Lange, 2017; Wang et al., 2018). We used a virtual survey on GSV images since it is $90 \%$ effective in tree identification at the genus level (Berland and Lange, 2017) and there is only one species of Ailanthus growing in Turkey. We used usually the Google Street View images which were taken in 2018. Points with $50 \mathrm{~m}$ spacing along OpenStreetMap road layer were generated. To solve issues with points which were too close due to parallel roads and topological errors in the vector data, the points were spatially thinned to 77200 points. Then, $10 \%$ of these points in each district were chosen by random sampling to represent the road density (Figure 2 Hiba! A hivatkozási forrás nem található.). However, since there are no Google Street View images in 2864 sample points, a total of 4856 sample points have been studied. While the least sample points on district basis was in Beşiktaş district with 78 points, the highest amount of sample points (with 584 points) was in Saryer district. Sample plots to be used for virtual survey were obtained by creating a circular buffer with a diameter of 50 meters at these randomly selected points. In order to collect virtual tree inventory data, the 50 meters long part of the roads within these sample plots were evaluated in two directions. In divided roads, one direction of the road is evaluated together with the central median. Trees at a maximum distance of approximately 3 meters from the roadside were taken into account. On some roads, trees that are 1.5-2 $\mathrm{m}$ away from the road but in a garden yet have the feature of road trees are also considered as road trees. 


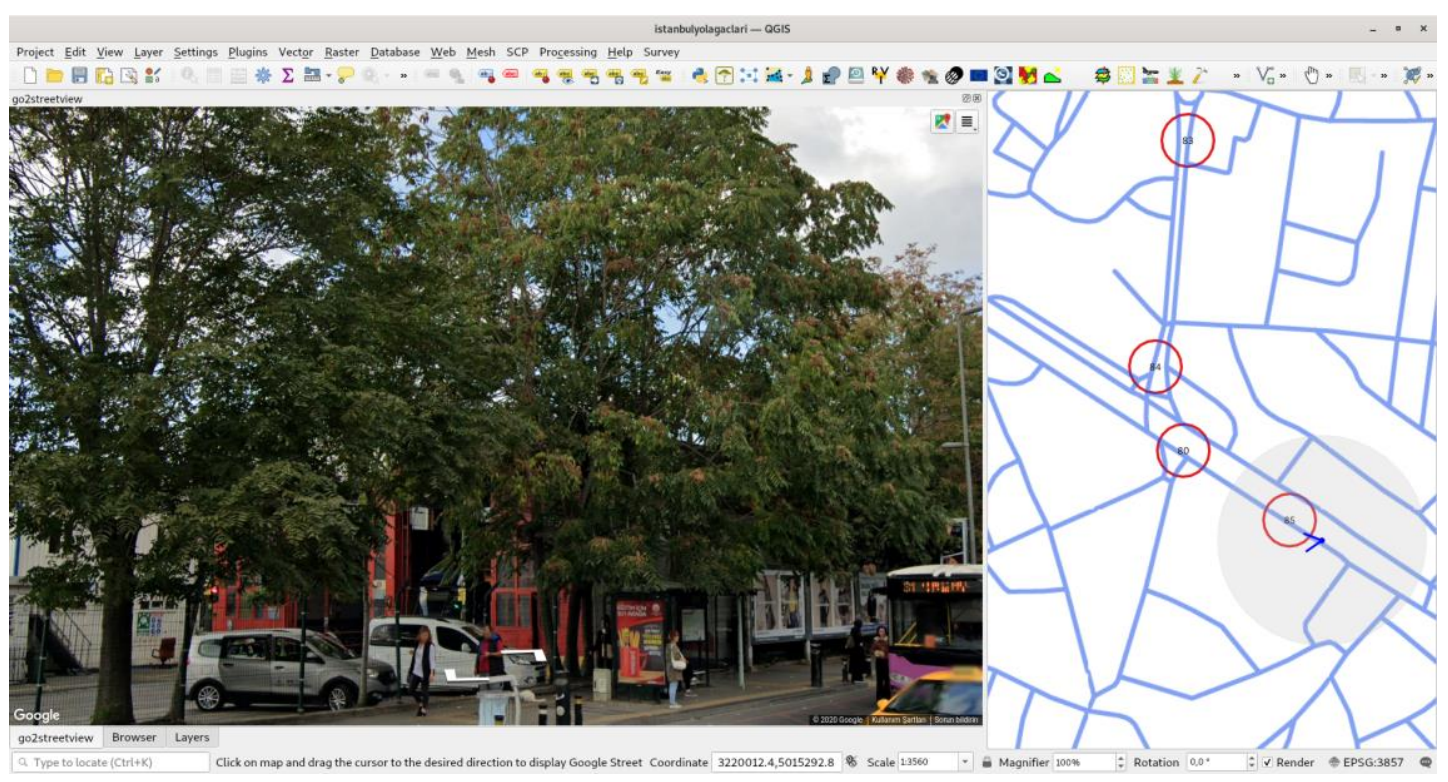

Figure 2. Virtual survey screen used in the study for tree identification

\section{Virtual tree identification}

The sample plots were visited virtually one by one using the "go2streetview" plugin in the Quantum GIS (QGIS.org, 2019) software, and the species identification and size estimates of the road trees were made (Figure 2). Considering approximately the diameter at breast height $(\mathrm{dbh})$, tree diameters were divided into the following classes: very large (diameter 40-50 cm), large (diameter 30-40 cm), medium (diameter 20-30 cm), small (diameter 10-20 cm), very small (diameter 5-10 cm). Tree heights were also estimated and grouped into the following classes: $5 \mathrm{~m}<, 5-10 \mathrm{~m}, 10-15 \mathrm{~m}, 15-20 \mathrm{~m}, 20 \mathrm{~m}>$.

For virtual survey, the google street-view images were synchronously provided to a 3-monitored computer. Three experts in plant systematics identified the trees displayed on their own monitor separately (three people giving the same plant number to each tree), estimated tree diameter and height, and recorded them. These records were then joined with the graphic object of the sample plots.

Since the tree of heaven can be easily identified in almost every season of the year with its bark, leaf and fruit characteristics, all three experts have mostly made the correct identification for the tree. In the sample plots where the identification of the species could not be made exactly in some winter photographs or where the diagnosis of three experts was not same, the control of the species identification was made on the street-view images taken at different dates. If the tree diameter and height estimation value by the three experts were all different, the average was taken, and in cases where the estimation of two experts was the same while the value from one expert was different, the estimation value from two agreeing experts was accepted.

\section{Results}

The number of Ailanthus altissima on the roads in the 21 districts of the European side of Istanbul differed greatly between districts (Table 1). Bayrampaşa was the district with the highest rate of Ailanthus altissima trees on the streets, with $6.19 \%$, followed by 
Beyoğlu with $5.7 \%$, Şişli with $4.87 \%$ whereas the lowest rates of Ailanthus altissima trees were reported for Beylikdüzü with $0.53 \%$, Güngören $0.87 \%$ and Başakşehir with $0.92 \%$ (Table 1).

Table 1. Total number of sample plots and Ailanthus altissima trees in the studied districts

\begin{tabular}{c|c|c|c|c|c}
\hline District & $\begin{array}{c}\text { Total number of } \\
\text { sample plots with } \\
\text { trees }\end{array}$ & $\begin{array}{c}\text { Total number } \\
\text { of sample plots }\end{array}$ & $\begin{array}{c}\text { Total number } \\
\text { of street trees }\end{array}$ & $\begin{array}{c}\text { Total number of } \\
\text { Ailanthus tree }\end{array}$ & $\begin{array}{c}\text { Percentage of } \\
\text { Ailanthus } \\
(\%)\end{array}$ \\
\hline Avcılar & 160 & 278 & 1212 & 24 & $\% 1.98$ \\
Bağcılar & 152 & 194 & 958 & 14 & $\% 1.46$ \\
Bahçelievler & 146 & 186 & 1005 & 23 & $\% 2.29$ \\
Bakırköy & 149 & 172 & 1213 & 25 & $\% 2.06$ \\
Başakşehir & 246 & 498 & 2165 & 20 & $\% 0.92$ \\
Bayrampaşa & 56 & 106 & 323 & 20 & $\% 6.19$ \\
Beşiktaş & 59 & 78 & 446 & 19 & $\% 4.26$ \\
Beylikdüzü & 211 & 302 & 2071 & 11 & $\% 0.53$ \\
Beyoğlu & 42 & 139 & 228 & 13 & $\% 5.70$ \\
Esenler & 60 & 83 & 349 & 6 & $\% 1.72$ \\
Esenyurt & 219 & 370 & 1582 & 14 & $\% 0.88$ \\
Eyüp & 181 & 450 & 1060 & 44 & $\% 4.15$ \\
Fatih & 155 & 262 & 948 & 40 & $\% 4.22$ \\
Gaziosmanpaşa & 83 & 120 & 474 & 8 & $\% 1.69$ \\
Güngören & 87 & 106 & 575 & 5 & $\% 0.87$ \\
Kağıtthane & 68 & 133 & 387 & 17 & $\% 4.39$ \\
Küçükçekmece & 197 & 304 & 1411 & 22 & $\% 1.56$ \\
Sarıyer & 161 & 584 & 1181 & 28 & $\% 2.37$ \\
Şişli & 114 & 225 & 677 & 33 & $\% 4.87$ \\
Sultangazi & 67 & 123 & 399 & 5 & $\% 1.25$ \\
Zeytinburnu & 78 & 143 & 496 & 13 & $\% 2.62$ \\
\hline Sum & 2691 & 4856 & 19160 & 404 & $\% 2.06$ \\
\hline
\end{tabular}

We recorded a total of 404 Ailanthus altissima trees, within 4856 sample plots (Table 1). The average ratio of tree of heaven in the total tree species composition was found to be $2.06 \%$ in the districts of Başakşehir, Beylikdüzü, Güngören ve Esenyurt (Table 1), having the lowest Ailanthus altissima tree rates among the street trees.

Of the total recorded trees of the species, diameters of 80 trees were less than $10 \mathrm{~cm}$ (20\%), 155 were $10-20 \mathrm{~cm}$ in diameter (38\%), 110 were $20-30 \mathrm{~cm}$ in diameter $(27 \%), 45$ were $30-40 \mathrm{~cm}$ in diameter (11\%), 8 were $40-50 \mathrm{~cm}$ (2\%) (Figure3). Regarding their heights, while 82 trees were less than $5 \mathrm{~m}$ tall (20\%), 228 were 5-10 m tall (56\%), 79 were $15-20 \mathrm{~m}$ tall (2\%), and 5 were more than $20 \mathrm{~m}$ tall (1\%) (Figure3). 


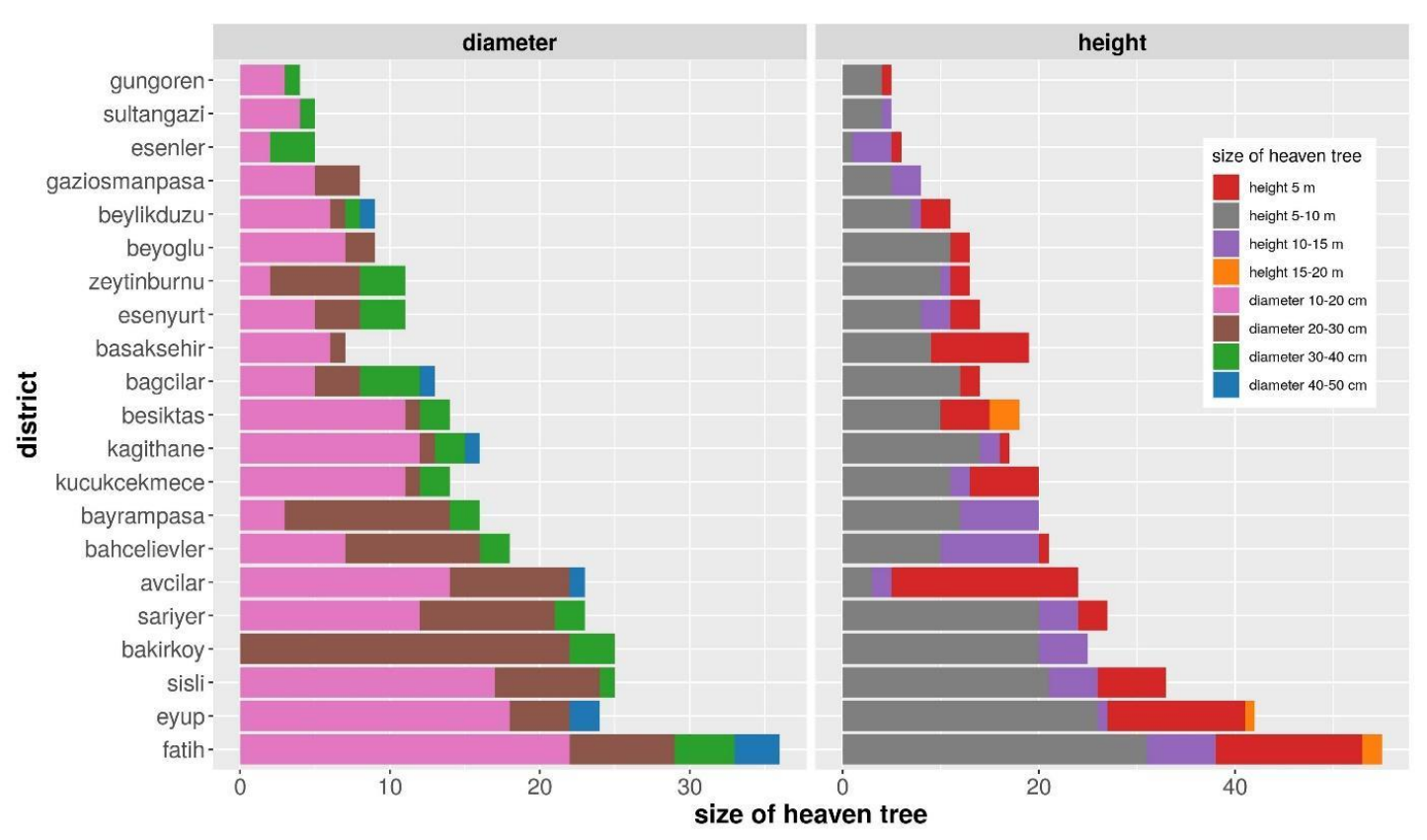

Figure 3. Diameter and height classes distribution of Ailanthus altissima trees in the 21 districts

\section{Discussion}

According to the analysis results, Ailanthus altissima with 404 trees constitutes $2.06 \%$ of the trees on the roadside in Istanbul. Although this number might seem low at first glance, considering that $10 \%$ of 77200 sample plots were studied and some of the sample plots did not have google images and 2165 sample plots did not have street trees and only trees within $3 \mathrm{~m}$ distance from the road were included, it can be understood that the real amount of A. altissima trees that spontaneously come to the roadsides is higher. In addition, stump sprouts, suckers and young seedlings with less than $5 \mathrm{~cm}$ in diameter were not included in the study.

Although not available in written sources, it is said that the tree of heaven was used during the construction of the railway in Istanbul between 1870-1890 (Yeşildal, 1994). A. altissima is not planted as a road tree in Istanbul, and people do not plant the tree in their gardens or surroundings (Yeşildal, 1994). Therefore, these trees of heaven detected on the roadsides are individuals that germinated from seeds that come to the roadside by wind, etc., and some of them have been preserved as road trees after reaching certain dimensions or individuals which have resprouted from the trees cut down during road maintenance works.

Most of the Ailanthus trees on the roadsides of Istanbul are young individuals belonging to the thin diameter classes developed from adventitious shoots or grown spontaneously from seed, while almost half of them are adult individuals capable of seeding (Figure 4). Casella and Vurro (2013) found that most of heaven trees on the roadsides were with a diameter of $8-18 \mathrm{~cm}$ in Bari, Italy. This result points to a significant spread and expansion in the Ailanthus population day by day. So, in İstanbul, the spreading, naturalization, and invasion process of the tree of heaven from urban areas to the surrounding abandoned lands, agricultural lands, pastures, forests continue slowly and unnoticed as in Switzerland (Wunder et al., 2016). 


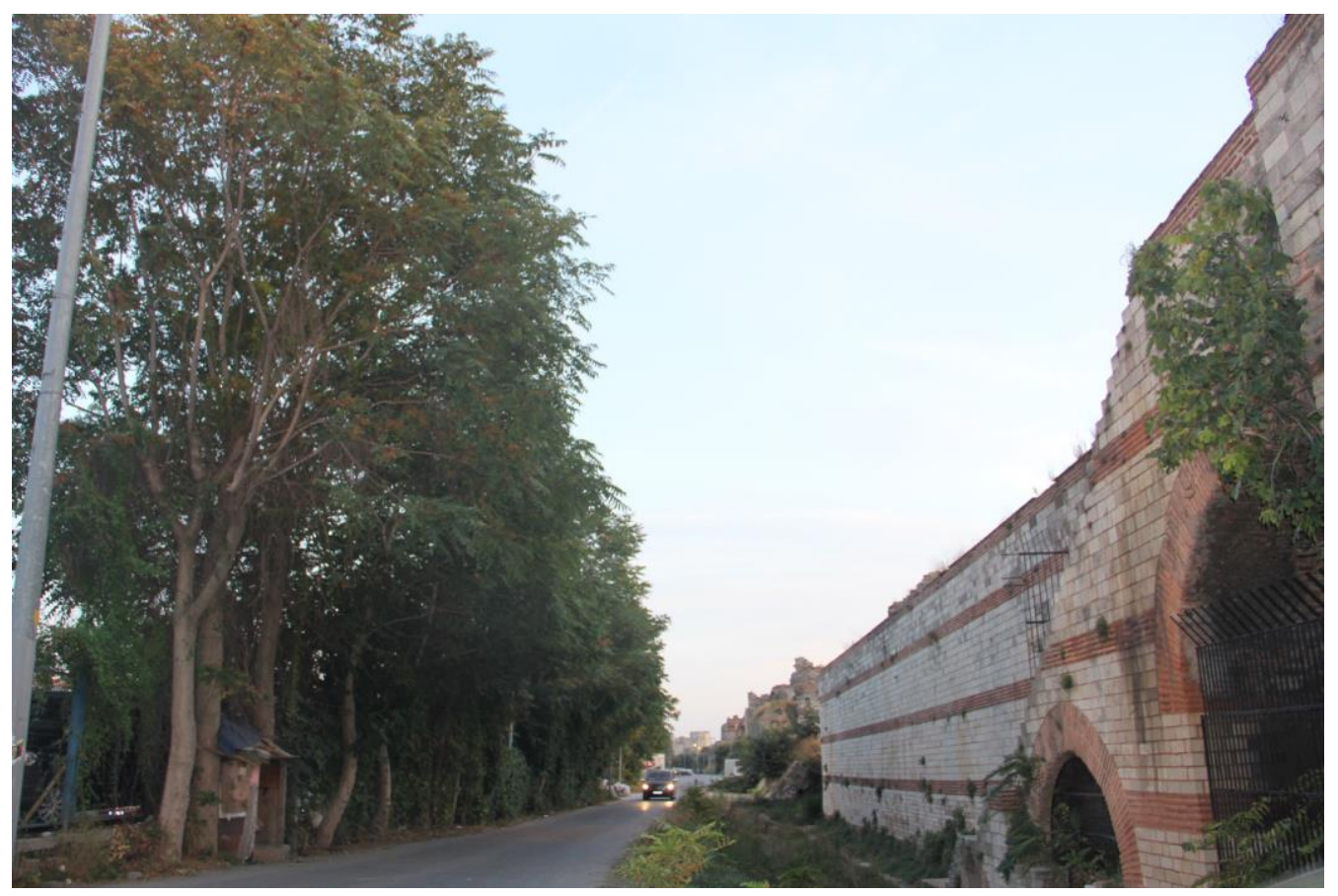

Figure 4. Ailanthus altissima trees which are spontaneously grown near old city walls of Istanbul

The intentional distribution of the species on the street of İstanbul can be prevented by conducting awareness campaigns about the environmental risks of invasive alien A. altissima trees for ornamental plant producers, local authorities, garden owners, and those living in the region. But among stakeholders who have a special interest in alien trees of cultural or ornamental value, it may not easily be accepted that the tree of heaven is an invasive species and needs to be tackled. Therefore, first of all, the opinions and perceptions about the benefits and negative invasive effects of A. altissima which is accepted as an invasive species almost all over the world, among the public and administrators should be guided by researches and informative brochures (Gaertner et al., 2017). Otherwise, it will not be easy and possible to manage the species in the peak and to prevent its spread by effective and appropriate struggle.

Invasive plant species have many negative environmental, economic and social impact (Tsiamus et al., 2021) but they also have some beneficial impacts environment and human well-being (Milanovic et al., 2020; Gallardo et al., 2020). There are two opposing views on the use of tree of heaven; one supports the use of the species, especially in problematic areas, due to its high ecological tolerance and adaptability and the other argues that they should not be used and should be removed because their negative effects on the environment outweigh their positive influences (Sladonja et al., 2015). Yeşildal (1994) recommended that limiting the areas where the trees of heaven can be used in the urban landscape of Istanbul and taking protection measures outside these areas The highly invasive feature of the species should not be overlooked in Istanbul, which is a city rich in plant diversity, with different habitats, and where residential areas penetrate into natural areas, and should be removed especially on roads in or near natural areas and on roads near historical buildings such as İstanbul city walls. The method to be used in combating A. altissima is determined depending on the location, age and density of the 
species. There are several control strategy methods such as mechanical control methods, chemical control and in recent years also biological control methods of treatment have been used in the control of Ailanthus (Ding et al., 2006; Kasson et al., 2019). If it is recognized early and quickly eliminated before it spreads, there will be no need for costly, tiring and time-consuming work. Similarly, in Europe (Folak et al., 2008), control strategies should be developed and applied to prevent the further spread of this species along the roadside in İstanbul and also in Turkey. Removing the Ailanthus on the roadside is also important in terms of improving road safety as it will provide the visibility of the road signs (Casella and Vurro, 2013). Kowarik and Böcker (1984) stated that Ailanthus was stung by root shoots up to natural bushes $25 \mathrm{~m}$ away from the roadside. In America, A. altissima is recommended to be removed from the right-of-way (ROW) due to the risk of invading the roadside and adjacent lands, even if it is at a distance that does not threaten the road safety (Gover et al., 2004). Perhaps, long-term, repeated, combined control methods will need to be applied to effectively remove the tree of heaven without damaging other street trees (Kettenring and Adams, 2011).

\section{Conclusion}

Ailanthus altissima stands out with its invasive character among the road trees of Istanbul. Ailanthus altissima trees, which are concentrated on partially controlled roadsides, are found in groups, especially in historic walls, open areas, and abandoned regions. The results of this study, which demonstrated the presence of Ailanthus altissima along Istanbul roads, will serve to provide a more targeted approach to the monitoring, containment and control of these invasive trees in İstanbul.

The management of combating A.altissima should be given priority in districts with the highest tree density of A. altissima and in areas where historical buildings, city walls, and historical aqueducts are located. This study has some limitations, as it was only conducted on roads for which GSVs are available. In future studies, the presence of scented trees in natural areas, parks and agricultural areas in Istanbul should be revealed in detail and the appropriate management method should be determined. In addition, in the future, by surveying the same areas on images taken at different dates or field survey, the spread of the A.altissima and the results of the struggle can be monitored.

The problem of alien and invasive plants should be seriously addressed in Turkey on a country-wide scale and immediate action plans should be prepared for monitoring and controlling these species which threaten ecosystems. A biosecurity strategy and a biosecurity policy should be established in Turkey for Ailanthus and other invasive species. For example, restrictions may be imposed on the cultivation and trade and planting of the tree of heaven as an ornamental plant in the country.

\section{REFERENCES}

[1] Andreu, J., Vilà, M., Hulme, P. E. (2009): An assessment of stakeholder perceptions and management of noxious alien plants in Spain. - Environmental Management 43: 12441255 .

[2] Asaro, C., Becker, C., Creighton, J. (2009): Control and utilization of tree-of-heaven, A guide for Virginia landowners. - Virginia Department of Forestry, Publication No P00144, Charlottesville, VA. 
[3] Berland, A., Lange, D. A. (2017): Google Street View shows promise for virtual street tree surveys. - Urban Forestry \& Urban Greening 21: 11-15.

[4] Brundu, G. (2017): Information on measures and related costs in relation to species considered for inclusion on the Union list: Ailanthus altissima. - Technical note prepared by IUCN for the European Commission.

[5] Casella, F., Vurro, M. (2013): Ailanthus altissima (tree of heaven): spread and harmfulness in a case-study urban area. - Arboricultural Journal 35(3): 172-181.

[6] Celesti-Grapow, L., Blasi, C. (2004): The role of alien and native weeds in the deterioration of archaeological remains in Italy. - Weed Technology 18: 1508-1513.

[7] Cullen, J. (1967): Ailanthus L. - In: Davis, P. H. (eds.) Flora of Turkey and East Aegean Islands, Vol. 2. Edinburg University Press, Edinburgh.

[8] Ding, J., Wu, Y., Zheng, H., Fu, W., Richard, R., Liu, M. (2006): Assessing potential biological control of the invasive plant, tree-of-heaven, Ailanthus altissima. - Biocontrol Science and Technology 16(6): 547-566.

[9] EPPO (2018): EPPO global database. - Retrieved $25^{\text {th }}$ October from https://gd.eppo.int/.

[10] European Commission (2019): Commission Implementing Regulation (EU)2019/1262 of 25 July 2019 amending Implementing Regulation (EU) 2016/1141 to update the list of invasive alien species of Union concern. - Retrieved $22^{\text {nd }}$ March 2021 from https://eur-lex.europa.eu/legal (accessed on 6 June 2020).

[11] Follak, S., Eberius, M., Essl, F., Furdos, A., Sedlacek, N., Trognitz, F. (2018): Invasive alien plants along roadsides in Europe. - EPPO Bulletin 48: 256-265.

[12] Gaertner, M., Novoa, A., Fried, J., Richardson, D. M. (2017): Managing invasive species in cities: a decision support framework applied to Cape Town. - Biological Invasions 19: 3461-3469.

[13] Gallardo, B., Bacher, S., Bradley, B., Comín, F. A., Gallien, L., Jeschke, J. M., Sorte, C. J. B., Vilà, M. (2019): InvasiBES: Understanding and managing the impacts of Invasive alien species on Biodiversity and Ecosystem Services. - NeoBiota 50: 1-109.

[14] Google (2019): Google Street View Image API. - Retrieved 21 ${ }^{\text {st }}$ March 2019 from https://developers.google.com/maps/documentation/ streetview.

[15] Gover, A., Kuhns, L., Johnson, J. (2004): Managing Tree of Heaven (Ailanthus altissima) on roadsides. - Retrieved July $20^{\text {th }} 2020$ from http://plantscience.psu.edu/research/projects/vegetative-

management/publications/roadside-vegetative-mangement-factsheets/3ailanthus-onroadsides.

[16] Hu, S. Y. (1979): Ailanthus. - Arnoldia 39: 29-50.

[17] Kasson, M. T., Kasson, L. R., Wickert, K. L., Davis, D. D., Staijich, J. E. (2019): Genome Sequence of a Lethal Vascular Wilt Fungus, Verticillium nonalfalfae, a Biological Control Used Against the Invasive Ailanthus altissima. - Microbiology 8(4): e1619-18.

[18] Kettenring, K. M., Adams, C. R. (2011): Lessons learned from invasive plant control experiments: a systematic review and meta-analysis. - Journal of Applied Ecology 48: 970979.

[19] Kowarik, I., Böcker, R. (1984): Zur Verbreitung, Vergesellschaftung und Einburgerung des Göotterbaumes (Ailanthus altissima [Mill.] Swingle) in Mitteleuropa. - Tuexenia 4: 929.

[20] Kowarik, I., Säumel, I. (2007): Biological flora of Central Europe: Ailanthus altissima (Mill.) Swingle. - Perspectives in Plant Ecology Evolution and Systematics 8(4): 207-237.

[21] Kowarik, I., von der Lippe, M. (2011): Secondary wind dispersal enhances long-distance dispersal of an invasive species in urban road corridors. - NeoBiota 9: 49-70.

[22] Li, X., Zhang, C., Li, W., Kuzovkina, Y. A., Weiner, D. (2015a): Who lives in greener neighborhoods? The distribution of street greenery and its association with residents' socio economic conditions in Hartford, Connecticut, USA. - Urban Forestry \& Urban Greening 14: 751-759. 
[23] Li, X., Zhang, C., Li, W., Ricard, R., Meng, Q., Zhang, W. (2015b): Assessing street-level urban greenery using Google Street View and a modified green view index. - Urban Forestry \& Urban Greening 14: 675-685.

[24] Meunier, G., Lavoie, C. (2012): Roads as corridors for invasive plant species: new evidence from smooth bedstraw (Galium mollugo). - Invasive Plant Science and Management 5: 92100.

[25] Milanović, M., Knapp, S., Pyšek, P., Kühn, I. (2020): Linking traits of invasive plants with ecosystem services and disservices. - Ecosystem Services 42: 101072.

[26] OpenStreetMap contributors (2019): Planet dump. - Retrieved March $25^{\text {th }} 2019$ from https://planet.osm.org. https://www.openstreetmap.org.

[27] Pysek, P., Lambdon, P. W., Arianoutsou, M., Kühn, I., Pino, J., Winter, M. (2009): Alien vascular plants of Europe. - In: DAISIE (ed.) Handbook of Alien Species in Europe. Springer, Berlin.

[28] QGIS.org (2019): QGIS Geographic Information System. Open Source Geospatial Foundation Project. - Retrieved June $3^{\text {rd }} 2020$ from http://qgis.org.

[29] Rebbeck, J., Jolliff, J. (2018): How long do seeds of the invasive tree, Ailanthus altissima remain viable? - Forest Ecology and Management 429: 175-179.

[30] Sheppard, A. W., Shaw, R. H., Sforza, R. (2006): Top 20 environmental weeds for classical biological control in Europe: a review of opportunities, regulations and other barriers to adoption. - Weed Research 46: 93-117.

[31] Sladonja, B., Sušek, M., Guillermio, J. (2015): Review on the invasive tree of heaven (Ailanthus altissima (Mill.) Swingle) conflicting values: assessment of its ecosystem services and potential biological threat. - Environmental Management 56: 1009-1034.

[32] Tsiamis, K., Deriu, I., Gervasini, E., D`amico, F., Katsanevakis, S., Cardoso, A. C. (2021): Baseline distribution of invasive alien species added to the list of Union concern in 2019, EUR 30631 EN. - Publications Office of the European Union, Luxembourg.

[33] TUIK (2020): Retrieved August $22^{\text {nd }} 2020$ from https://data.tuik.gov.tr/tr/main-categorysub-categories-sub-components $2 / \#$.

[34] Uludağ, A. (2015): Ailanthus altissima. - In: Önen, H. (ed.) Türkiye İstilacı Bitkiler Kataloğu (Catalogue of the invasive plants of Turkey). Turkish Ministry of Food, Agriculture and Livestock, Ankara.

[35] Wang, W., Xiao, L., Zhang, J., Yang, Y., Tian, P., Wang, H., He, X. (2018): Potential of internet street-view images for measuring tree sizes in roadside forests. - Urban Forestry \& Urban Greening 35: 211-220.

[36] Wickert, K. L., O’Neal, E. S., Davis, D. D., Kasson, M. T. (2017): Seed production, viability, and reproductive limits of the invasive Ailanthus altissima (Tree-of-Heaven) within invaded environments. - Forests 8: 226.

[37] Wunder, J., Knüsel, S., Gurtner, D., Conedera, M. (2016): The spread of tree of heaven in Switzerland. - In: Krumm, F., Vitková, L. (eds.) Introduced tree species in European forests: opportunities and challenges. European Forest Institute.

[38] Yeşildal, B. (1994): Kokarağaçların genel özellikleri ve İstanbul Peyzajı açısından analizi (Main characteristic of the tree of heaven (Ailanthus altissima) and its respective effect on landscape of İstanbul). - Master Thesis, Y1ldız Technical University, Institute of Science, İstanbul. 